\title{
Two synonyms for Hadrophallus bubalus (Fabricius) (Hemiptera, Membracidae)
}

\author{
Gabriel S. de Andrade
}

Centro de Ciências Biológicas e da Saúde, Universidade Estadual do Oeste do Paraná. Rua Universitária 2069, Caixa Postal 711, 85819-110 Cascavel, Paraná, Brasil. E-mail: gsa@certto.com.br

\begin{abstract}
Two synonyms are considered: Hadrophallus bubalus (Fabricius, 1794) = Ceresa integra Walker, 1858 syn. nov. = Ceresa borealis Fairmaire, 1846 syn. restaur. The species Spissistilus constans (Walker, 1851) sensu Caldwell, 1949 is considered a misidentification of $H$. bubalus.

KEY WORDS. Ceresini, Membracoidea, Smiliinae, systematics, taxonomy.
\end{abstract}

RESUMO. Dois sinônimos para Hadrophallus bubalus (Fabricius) (Hemiptera, Membracidae). Dois sinônimos são considerados: Hadrophallus bubalus (Fabricius, 1794) = Ceresa integra Walker, 1858 syn. nov. = Ceresa borealis Fairmaire, 1846 syn. restaur. A espécie Spissistilus constans (Walker, 1851) sensu Caldwell, 1949 é considerada interpretação errônea de $H$. bubalus.

PALAVRAS CHAVE. Ceresini, Membracoidea, sistemática, Smiliinae, taxonomia.

\section{Hadrophallus bubalus (Fabricius, 1794)}

Membracis Bubalus (sic) Fabricius, 1794: 14.

Membracis (Bubalus) Bubalis (sic); Zimsen, 1964: 286 (rep. typ.).

Ceresa bubalus; McKamey, 1998: 244 (cat.).

Hadrophallus bubalus; Andrade, 1997: 290 (syn.).

Ceresa borealis Fairmaire, 1846: 284. Syn. restaur.

Hadrophallus borealis; McKamey, 1998: 250 (cat.).

Ceresa integra Walker, 1858: 67; Broomfield, 1971: 356 (tip.); McKamey, 1998: 245 (cat.). Syn. nov.

Spissistilus constans; Caldwell, 1949: 514, pl. 22, non Thelia constans Walker, 1851. (misidentification).

The comparative study of the female lectotype of Membracis bubalus Fabricius, deposited in the "Zoologisk Museum" (København), and of material identified as Hadrophallus borealis (Fairmaire), according to DenNIs (1952) and KopP \& YoNKE (1979) interpretations, showed that they are the same species, corroborating the synonymy proposed by STÅL (1869).

Equally, the study of the male lectotype of Ceresa integra Walker, deposited in "The Natural History Museum" (London), showed that it is also the same species.

Goding (1929) placed C. integra Walker in the synonymy of C. malina (Germar, 1835). The comparative study of the original description and of the lectotype of $C$. integra Walker with material considered as C. malina, following the interpretation of Remes-Lenicov (1973) and Andrade (2004), showed that they are different species.

The species interpreted by REMES-LenICOV (1973) as C. in- tegra Walker was described as a different species in ANDRADE (2002).

And, finally, the exam of the illustrations presented by CALDwell (1949) for Spissistilus constans (Walker), showed to be identical to Hadrophallus bubalus (Fabricius), probably due to erroneus identification.

\section{ACKNOWLEDGEMENTS}

I am indebted to Mick D. Webb (The Natural History Museum, London, UK), for the courtesy during my visit to the Institution and opportunities for the studies in the Membracidae collections, and to Dr Nills Møller Andersen (Zoologisk Museum, København, Denmark), for the loan of Fabricius' type material.

\section{REFERENCES}

ANDRADE, G.S. 1997. Stictocephala alta (Walker,1851) sp. rev., comb. nov., the correct name for the "buffalo treehopper", with $S$. bisonia Kopp \& Yonke, 1977 as a new synonym, and notes on Hadrophallus bubalus (Fabricius, 1794) comb. nov. (Homoptera: Membracidae). Transactions of the American Entomological Society, Philadelphia, 123 (4): 289-295.

ANDRADE, G.S. 2002. Sobre quatro novas espécies de Ceresa Amyot \& Serville (Hemiptera, Auchenorrhyncha, Membracidae). Revista Brasileira de Zoologia, Curitiba, 19 (Supl. 2): 3951.

Andrade, G.S. 2004. As espécies do gênero Ceresa Amyot \& Serville (Hemiptera, Auchenorrhyncha, Membracidae). Re- 
vista Brasileira de Zoologia, Curitiba, 21 (4): 671-738.

Broomfield, P.S. 1971. A catalogue of the Membracid types (Homoptera: Membracidae) in the British Museum (Natural History). Bulletin of the British Museum of Natural History, London, 25 (8): 325-386.

Caldwell, J.S. 1949. A generic revision of the treehoppers of the tribe Ceresini in America north of Mexico, based on a study of the male genitalia. Proceedings of the United States National Museum, Washington, 98: 491-521.

DenNIs, C.J. 1952. Genitalia of the Membracidae of Wisconsin. Canadian Entomologist, Guelph, 84 (6): 157-173.

FABRICIUS, J.C. 1794. Entomologia systematica emendata et aucta 4. Hafniae, 472p.

FAirmaire, L.H.M. 1846. Revue de la tribu des Membracides. Annales de la Société Entomologique de France, Paris, 4: 235-320.

Germar, E.F. 1835. Species Membracidum Musae E.F. Germari. Revue Entomologique, Strasbourg, 3: 223-262.

Goding, F.W. 1929. The Membracidae of South America and the Antilles. IV. Subfamilies Hoplophorioninae, Darninae, Smiliinae, Tragopinae (Homoptera). Transactions of the American Entomological Society, Philadelphia, 55: 197330.

Kopp, D.D. \& T.R. YonKe. 1979. A taxonomic review of the tribe
Ceresini (Homoptera: Membracidae). Miscellaneous Publications of the Entomological Society of America, College Park, 11 (2): 1-97.

McKamey, S.H. 1998. Taxonomic catalogue of the Membracoidea (Exclusive of Leafhoppers) - Second supplement to Fascicle 1 - Membracidae of the General Catalogue of the Hemiptera. Memoirs of the American Entomological Institute, Gainesville, 60: 1-377.

Remes-Lenicov, A.M.M. 1973. Contribución al estudio de los Membrácidos neotropicales I. Revisión del género "Ceresa" (sic) Amyot et Serville. Acta Zoologica Lilloana, Tucumán, 30: 53-134.

STÅL, C. 1869. Hemiptera Fabriciana. Fabricianska Hemipterarter, efter de i Köpenhamn och Kiel förvarade typexemplaren granskade och beskrifne. 2. Kongliga Svenska VetenskapsAkademiens Förhandlingar, Stockholm, 8 (1): 1-130.

WALKER, F. 1851. List of the specimens of homopterous insects in the collection of the British Museum. London, 2: 261636.

WALKER, F. 1858. Insecta saundersiana: or characteres of undescribed insects in the collection of William Wilson Saunders, Esq. Homoptera. London, J.V. Voorst, 117p.

Zimzen, E. 1964. The type material of I.C. Fabricius. Copenhagen, Munksgaard, 656p.

Received in 22.III.2005; accepted in 28.VIII.2005. 